\title{
Reelin Regulates the Development and Synaptogenesis of the Layer-Specific Entorhino-Hippocampal Connections
}

\author{
Víctor Borrell, ${ }^{1}$ José A. Del Río,, ${ }^{1}$ Soledad Alcántara, ${ }^{1}$ Michèle Derer, ${ }^{2}$ Albert Martínez, ${ }^{1}$ \\ Gabriella D'Arcangelo, ${ }^{3}$ Kazunori Nakajima, ${ }^{4}$ Katsuhiko Mikoshiba, ${ }^{5}$ Paul Derer, ${ }^{2}$ Tom Curran, ${ }^{3}$ and \\ Eduardo Soriano ${ }^{1}$
}

${ }^{1}$ Department of Animal and Plant Cell Biology, University of Barcelona, Barcelona 08028, Spain, ${ }^{2}$ Developmental Neurobiology Laboratory, Pierre et Marie Curie University, Paris 75005, France, ${ }^{3}$ Department of Developmental Neurobiology, St. Jude Children's Research Hospital, Memphis, Tennessee 38105, ${ }^{4}$ Department of Molecular Neurobiology, Institute of DNA Medicine, Research Center for Medical Science, The Jikei University School of Medicine, 3-25-8 Nishi-shimbashi, Minato-ku, Tokyo 105-8461, Japan, and 5Department of Molecular Neurobiology, The Institute of Medical Science, University of Tokyo, 4-6-1 Shirokanedai, Minato-ku, Tokyo 108, Japan

Here we examine the role of Reelin, an extracellular protein involved in neuronal migration, in the formation of hippocampal connections. Both at prenatal and postnatal stages, the general laminar and topographic distribution of entorhinal projections is preserved in the hippocampus of reeler mutant mice, in the absence of Reelin. However, developing and adult entorhinal afferents show severe alterations, including increased numbers of misrouted fibers and the formation of abnormal patches of termination from the medial and lateral entorhinal cortices. At perinatal stages, single entorhinal axons in reeler mice are grouped into thick bundles, and they have decreased axonal branching and decreased extension of axon collaterals. We also show that the number of entorhino-hippocampal synapses is lower in reeler mice than in control animals during development. Studies performed in mixed entorhino-hippocampal cocultures combining slices from reeler and wild-type mice indicate that these abnormalities are caused by the lack of Reelin in the target hippocampus. These findings imply that Reelin fulfills a modulatory role during the formation of layer-specific and topographic connections in the hippocampus. They also suggest that Reelin promotes maturation of single fibers and synaptogenesis by entorhinal afferents.

Key words: Reelin; Cajal-Retzius cells; synaptic specificity; neuronal connections; hippocampus; reeler mutant mouse
The formation of initial neural projections depends on diffusible and membrane-anchored factors, whereas neurotrophins and neuronal activity are believed to shape final axonal arbors (Katz and Shatz, 1996; Tessier-Lavigne and Goodman, 1996). In addition, cell adhesion molecules and extracellular matrix proteins contribute to the growth and targeting of developing axons (Stoeckli and Landmesser, 1995; Faissner, 1997; Gotz et al., 1997; Inoue and Sanes, 1997).

In many brain regions neural connections are organized in specific laminae. The main afferents to the hippocampus terminate in a laminar manner in which distinct synaptic inputs innervate nonoverlapping layers. Thus, entorhinal afferents innervate the stratum lacunosum-moleculare (SLM) and the outer molecular layer (OML) and, conversely, the commissural/associational

\footnotetext{
Received Aug. 28, 1998; revised Nov. 30, 1998; accepted Dec. 2, 1998.

This work was supported by The Marató de TV3 Foundation, the Direccion General de Investigación Científica y Técnica (Grant P.M.95-0102) and Comisión Interministerial de Ciencia y Tecnología, Spain (Grant SAF98-0106), the Ramón Areces Foundation and the International Institute for Research in Paraplegia (E.S.), by the President's Special Research Grant (The Institute of Physical and Chemical Research) and the Ministry of Education, Science, and Culture of Japan (K.N.), National Institutes of Health Cancer Center Support CORE grant (T.C.), a grant from the National Institute of Neurological Diseases and Stroke (NINDS) (T.C.), the American Lebanese Syrian Associated Charities (ALSAC) (G.D., T.C.), and a National Research Service Award from NINDS (G.D.). V.B. was supported by a Comisió Interdepartamental de Recerca i Tecnologia-FPI fellowship. We thank R. Rycroft for editorial assistance.

Correspondence should be addressed to Dr. Eduardo Soriano, Department of Animal and Plant Cell Biology, Faculty of Biology, University of Barcelona, Av. Diagonal 645, Barcelona 08028, Spain.

Copyright (C) 1999 Society for Neuroscience $\quad 0270-6474 / 99 / 191345-14 \$ 05.00 / 0$
}

fibers terminate in the stratum oriens (SO), stratum radiatum (SR), and inner molecular layer (Blackstad, 1956; Steward, 1976; Steward and Scoville, 1976; Swanson and Cowan, 1977; Swanson et al., 1978; Ruth et al., 1982; Amaral and Witter, 1995). Tracing studies in embryos have shown that hippocampal afferents invade their target layers as soon as they enter the hippocampus, which suggests that specific laminar cues are already present at these stages (Supèr and Soriano, 1994; Supèr et al., 1998a,b). This is consistent with slice culture experiments showing that the layerspecific targeting of hippocampal afferents does not depend on the temporal order of fiber arrival (Frotscher and Heimrich, 1993).

Cajal-Retzius (CR) cells are a special class of pioneer neuron in the marginal zone-layer I of the cerebral cortex (MarínPadilla, 1978; Edmunds and Parnavelas, 1982; Marín-Padilla and Marín-Padilla, 1982; Derer and Derer, 1990). These neurons are also very abundant in the hippocampus, where they are arranged in a single layer, the outer marginal zone-SLM (Soriano et al., 1994; Del Río et al., 1995, 1996). At the time of ingrowth, entorhinal fibers overlap extensively and form transient synaptic contacts with CR cells (Supèr and Soriano, 1994; Supèr et al., 1998a). The ablation of hippocampal CR cells in organotypic cultures prevents the ingrowth of entorhinal afferents to the hippocampus (Del Río et al., 1997), indicating that pioneer CR cells play an important role in the guidance and targeting of layer-specific hippocampal connections.

The reelin gene, which is responsible for the reeler mutation and encodes a large extracellular matrix protein, is highly ex- 
pressed in CR cells (D'Arcangelo et al., 1995, 1997; Hirotsune et al., 1995; Ogawa et al., 1995; Nakajima et al., 1997; Schiffmann et al., 1997; Alcántara et al., 1998). Incubation of entorhinohippocampal slices with anti-Reelin antibodies resulted in decreased innervation and reduced branching and growth of entorhinal afferents (Del Río et al., 1997). Preliminary studies in vivo suggested that similar alterations may occur in reeler mutant mice, suggesting a novel role for Reelin in axonal growth (Del Río et al., 1997; Holt and Harris, 1998).

Here we analyze the development of the entorhinohippocampal connection in reeler mice. We show that reelin is expressed in CR cells before and during the arrival of entorhinal afferents, and that its absence leads to alterations in the entorhino-hippocampal pathway, including reduced axonal branching, and an increase in the number of misrouted aberrant fibers. Some of these abnormalities are transient, because they are not detectable in adult reeler mice. Furthermore, we show that reeler mice have fewer entorhino-hippocampal synapses, which indicates a role for Reelin in synaptogenesis. Finally, because reelin is expressed in the entorhinal cortex, mixed organotypic co-cultures of reeler and heterozygous slices were prepared to determine the contribution of Reelin produced by the target region to the pattern of afferent termination.

\section{MATERIALS AND METHODS}

Animals. OF1 mice (IFFA-Credo, Lyon, France) were used for the mRNA in situ hybridization studies. For tracing studies, reeler and heterozygous mice were obtained by mating reeler $\left(\operatorname{Re} \ln ^{\mathrm{rl}}, \mathrm{BALB} / \mathrm{c}\right)$ homozygous $(r l / r l)$ males with heterozygous $(r l /+)$ females; BALB/c and OF1 mice were used as controls $(+/+)$. The day on which a vaginal plug was detected was considered embryonic day 0 (E0), and the day of birth was considered postnatal day $0(\mathrm{P} 0)$.

In situ hybridization and immunocytochemistry. Embryos from E12, E14, E16, and E18 stages, mice from postnatal stages P0, P5, P10, P15, and P21, and adults (two to three animals each) were perfused with phosphate-buffered (PB) 4\% paraformaldehyde. The brains were postfixed with the same fixative, cryoprotected with $30 \%$ sucrose, and sectioned at $25-60 \mu \mathrm{m}$. A reelin antisense riboprobe was labeled with digoxigenin-d-UTP (Boehringer Mannheim, Mannheim, Germany) by in vitro transcription of a $2.2 \mathrm{kbp}$ fragment encoding mouse reelin (D'Arcangelo et al., 1995) using T3 polymerase (Ambion).

In situ hybridization was performed on free-floating sections essentially as described elsewhere (de Lecea et al., 1994; Alcántara et al., 1996). Briefly, sections were permeabilized, deproteinized, and acetylated. Thereafter, sections were prehybridized in a solution containing $50 \%$ formamide, $10 \%$ dextran sulfate, $5 \times$ Denhardt's, $0.62 \mathrm{M} \mathrm{NaCl}, 10$ mM EDTA, 20 mм PIPES, pH 6.8, 50 mm 1,4-dithio-DL-threitol (DTT), $250 \mathrm{mg} / \mathrm{ml}$ yeast RNA, and $250 \mathrm{mg} / \mathrm{ml}$ denatured salmon sperm DNA for $3 \mathrm{hr}$ at $60^{\circ} \mathrm{C}$. Sections were then incubated overnight at $60^{\circ} \mathrm{C}$ in the same solution containing the labeled antisense RNA riboprobe (200-500 ng/ $\mathrm{ml}$ ). Thereafter, sections were treated with RNase A, washed in $0.5 \times$ $\mathrm{SSC} / 50 \%$ formamide $\left(55^{\circ} \mathrm{C}\right)$ and in $0.1 \times \mathrm{SSC} / 0.1 \%$ sarkosyl $\left(60^{\circ} \mathrm{C}\right)$. Sections were then rinsed and incubated with an anti-digoxigenin antibody conjugated to alkaline phosphatase. After washing, sections were developed with nitroblue tetrazolium salt and 5-bromo-4-chloro-3indolyl phosphate, toluidinium salt, mounted onto gelatinized slides, and coverslipped with Mowiol. Some sections were immunostained with rabbit antibodies against calbindin (1:6000) or calretinin (1:3000) (Swant antibodies, Bellizona, Switzerland). Primary antibodies were visualized using biotinylated anti-rabbit antibodies and the avidin-biotin-peroxidase complex (ABC; Vector Labs, Burlingame, CA). The peroxidase reaction was developed using diaminobenzidine (DAB) and $\mathrm{H}_{2} \mathrm{O}_{2}$ as substrates. Sections were mounted and coverslipped as above.

Controls including hybridization with a sense riboprobe or omission of the primary antibodies prevented hybridization or immunohistochemical signals.

Tracing of the entorhino-hippocampal pathway in vivo. Pregnant mice were killed by an overdose of ether at embryonic stages E16-E18. Embryos were perfused with $4 \%$ paraformaldehyde in $0.1 \mathrm{M} \mathrm{PB}$. A single injection of DiI (Molecular Probes, Eugene, OR) was delivered into the entorhinal cortex via a glass micropipette (Supèr and Soriano, 1994), under inspection through a microscope $(8 \mathrm{rl} /+, 15 \mathrm{rl} / \mathrm{rl}, 7+/+)$. Then, brains were stored in fixative for 3-4 weeks in the dark. Coronal vibratome sections ( $80 \mu \mathrm{m}$ thick) were counterstained with bisbenzimide, mounted, and coverslipped with Mowiol. Postnatal and adult reeler, heterozygous, and wild-type mice (P1: $15 r l / r l, 13 r l /+, 7+/+$; P4: $10 r l / r l$, $10 \mathrm{rl} /+, 6+/+$; P11: $8 \mathrm{rl} / \mathrm{rl}, 15 \mathrm{rl} /+, 4+/+)$ and adult mice $(13 \mathrm{rl} / \mathrm{rl}, 6 \mathrm{rl} /+$, $3+/+)$ were iontophoretically injected with biocytin in the entorhinal cortex $(+7.6 \mu \mathrm{A} ; 2 \mathrm{sec}$ on, $1 \mathrm{sec}$ off). After $24 \mathrm{hr}$ of survival, animals were perfused with $4 \%$ paraformaldehyde, and the brains were post-fixed overnight at $4^{\circ} \mathrm{C}$. After cryoprotection, brains were cut either coronally or horizontally (50 $\mu \mathrm{m}$ thick). After blocking endogenous peroxidase activity, sections were incubated with $\mathrm{ABC}$ and developed with a DAB nickel-enhanced reaction (black reaction product); sections were counterstained with Nissl stain or immunostained for calretinin, as described elsewhere (Del Río et al., 1996) using DAB (brown product). In some cases, sections were incubated with anti-calretinin antibody and streptavidin-Texas Red overnight, rinsed several times, and incubated with a secondary antibody bound to fluorescein. These sections were analyzed with a confocal microscope.

Electron microscopy. Postnatal mice (P2: $2 r l /+, 1 r l / r l ; \mathrm{P} 5: 6 r l /+, 4 r l / r l)$ were injected in the entorhinal cortex with biocytin for the tracing of the entorhino-hippocampal pathway. After $24 \mathrm{hr}$ of survival animals were anesthetized with ether and perfused with $4 \%$ paraformaldehyde and $0.1-0.2 \%$ glutaraldehyde in PB. Vibratome sections were processed for the visualization of biocytin as above. Uninjected animals were also perfused and vibratome-sectioned (P2: $4 r l /+, 2 r l / r l ; P 5: 4 r l /+, 5 r l / r l)$. Tissue slices were post-fixed with osmium tetroxide, stained with uranyl acetate, and flat-embedded in araldite. Thin sections were collected onto Formvar-coated slot grids and stained with lead citrate. Quantitative analyses were performed on a series of electron micrographs taken at random in the SLM and OML (final magnification 16,000×).

Reeler co-culture experiments. Entorhino-hippocampal slice co-cultures were prepared from P0-P1 mice essentially as described (Frotscher and Heimrich, 1993; Del Río et al., 1996, 1997). Animals were anesthetized by hypothermia, and the hippocampus and prospective parietal cortex were dissected out. Tissue pieces were cut into transverse slices (300-350 $\mu \mathrm{m}$ thick) using a McIlwain tissue chopper, and the slices were maintained in Minimum Essential Medium (MEM) supplemented with L-glutamine $(2 \mathrm{mM})$ for $45 \mathrm{~min}$ at $4^{\circ} \mathrm{C}$. Selected slices were co-cultured using the membrane interface technique (Stoppini et al., 1991). Incubation medium was 50\% MEM, 25\% horse serum, 25\% HBSS, supplemented with L-glutamine ( $2 \mathrm{~mm}$ ). The reeler or normal (heterozygous) phenotype of the pups was determined by the cytoarchitectonics of the hippocampus, clearly discernible in slices under dark-field optics. Slices from reeler mice displayed a disrupted dentate gyrus and a typical double-layered pyramidal layer. Five types of co-cultures were prepared as follows: (1) wild-type co-cultures $\left(\mathrm{E}^{+/+} / \mathrm{H}^{+/+}\right)(n=27)$ and $(2)$ heterozygous co-cultures $\left(\mathrm{E}^{r l /+} / \mathrm{H}^{r l /+}\right)(n=25)$, where both slices were from wild-type and heterozygous animals, respectively; (3) reeler cocultures $\left(\mathrm{E}^{r l / r l} / \mathrm{H}^{r l / r l}\right)(n=40)$, in which the tissue pieces were from reeler pups; (4) mixed co-cultures using hippocampi from reeler and entorhinal cortices from heterozygous pups $\left(\mathrm{E}^{r l /+} / \mathrm{H}^{r l / r l}\right)(n=44)$; and (5) mixed co-cultures combining heterozygous hippocampi with reeler entorhinal cortex slices $\left(\mathrm{E}^{r l / r l} / \mathrm{H}^{r l++}\right)(n=56)$. To assess the formation of entorhinohippocampal connections, a crystal of biocytin was injected into the entorhinal slice $24 \mathrm{hr}$ before fixation (Del Río et al., 1997). Co-cultures were fixed after $7 \mathrm{~d}$ in vitro (DIV) and 15 DIV with $4 \%$ paraformaldehyde in $0.1 \mathrm{M} \mathrm{PB}$. After several rinses, $40-\mu \mathrm{m}$-thick sections were obtained, blocked with $10 \%$ normal goat serum, and incubated with the $\mathrm{ABC}$ overnight at $4^{\circ} \mathrm{C}$. After development with a nickel-enhanced DAB reaction, sections were counterstained with Nissl stain. In some cases, sections were processed for the detection of calretinin as described (brown product).

Quantitative analysis. Selected biocytin-labeled fibers were drawn using a $100 \times$ objective lens and a camera lucida ( 23 to 47 fibers per group and age). Lengths were measured using a planimeter and the branching index (number of branching points per $100 \mu \mathrm{m}$ ), lengths of side collaterals (in micrometers), and density of boutons (number of axonal varicosities per $100 \mu \mathrm{m})$ were calculated.

The density of synaptic contacts was counted in $16,000 \times$ electron micrographs (each of $80 \mu \mathrm{m}^{2} ; 26$ to 30 photographs per group, obtained from two animals). The length of the synaptic contacts was drawn and measured using an IMAT image analyzer (Scientific and Technical 

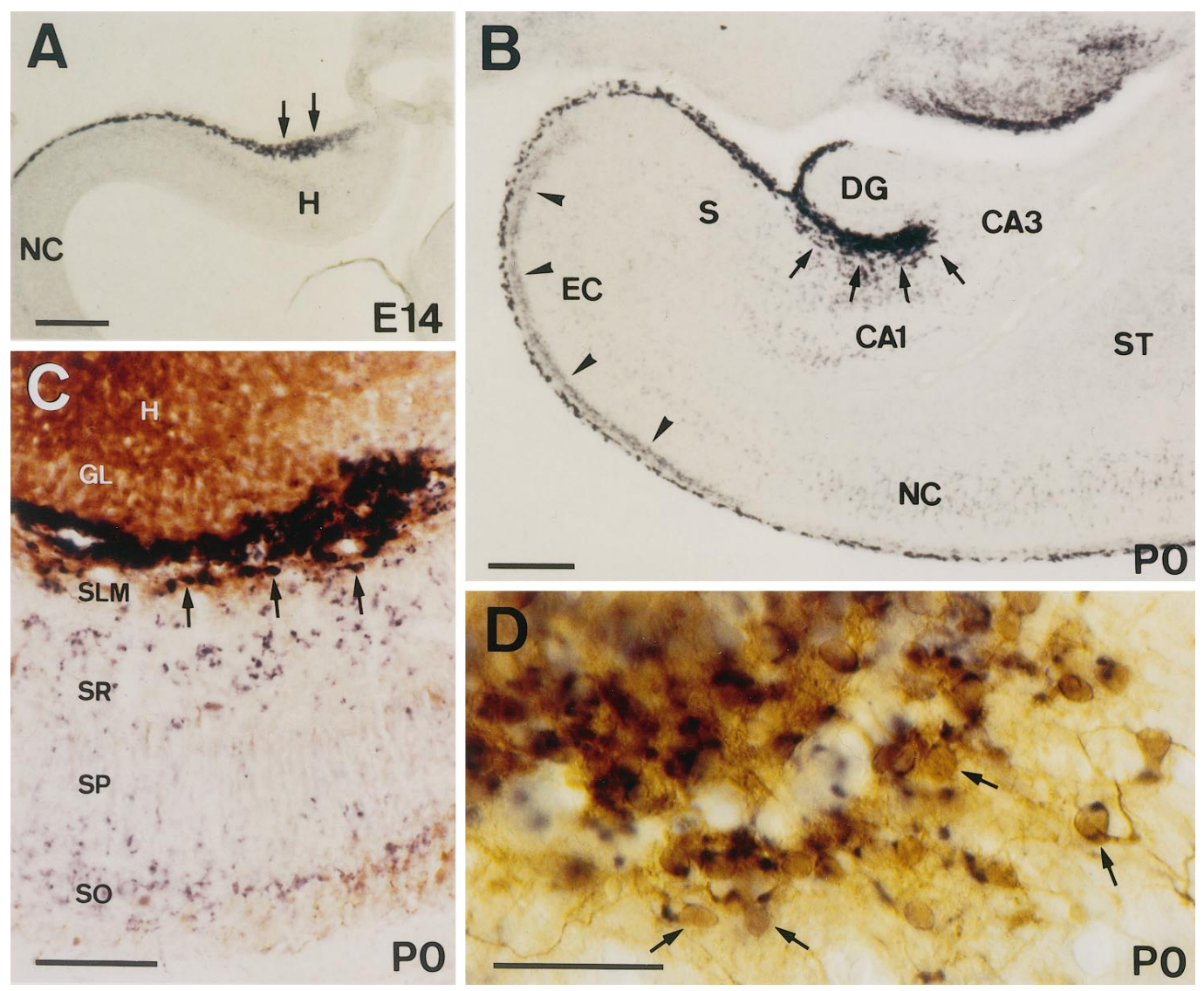

Figure 1. Expression of reelin mRNA during mouse hippocampal development. $A, B$, Panoramic views of the hippocampal region illustrating the distribution of reelin mRNA-expressing cells (blue reaction product) at $\mathrm{E} 14(A)$ and $\mathrm{P} 0(B)$ in coronal $(A)$ and horizontal $(B)$ sections. At E14 $(A)$, reelin-positive cells are mostly located in the marginal zone (arrows) of the hippocampal primordium $(H)$. At P0 $(B)$, reelin-expressing cells are densely packed near the hippocampal fissure (arrows) in the molecular layer of the dentate gyrus and the hippocampal stratum lacunosum-moleculare, as well as throughout layers I and II (arrowheads) of the entorhinal cortex $(E C)$. $C, D$, Medium $(C)$ and high $(D)$ magnification photomicrographs of reelin mRNA hybridized sections (blue reaction product) processed for calretinin immunolabeling (brown reaction product) at P0. Cajal-Retzius cells identified by calretinin antibodies contain reelin mRNA (arrows). $C A 3, C A 1$, Hippocampal subfields; $D G$, dentate gyrus; $G L$, granular layer; $H$, hilus; $N C$, neocortex; $S$, subiculum; $S L M$, stratum lacunosum-moleculare; $S O$, stratum oriens; $S P$, stratum pyramidale; $S R$, stratum radiatum; $S T$, striatum. Scale bars: $A, B, 200 \mu \mathrm{m} ; C, 100 \mu \mathrm{m} ; D, 25 \mu \mathrm{m}$.

Services, University of Barcelona). ANOVA least significant difference (LSD) tests were run to analyze the significance of differences.

Co-cultures were classified as shown in Table 1. Co-cultures receiving similar biocytin injections were viewed with a $40 \times$ oil-immersion objective lens and a millimetric eyepiece. Axons crossing a $75 \mu \mathrm{m}$ bar were counted on a single focus plane (three to six counts per culture).

\section{RESULTS}

\section{reelin is expressed before and during the formation of hippocampal connections}

To investigate the developmental expression pattern of reelin in the hippocampal region, embryos and postnatal mice were processed for in situ hybridization. reelin mRNA was detected at E12-E14 (preplate stage) (Soriano et al., 1994) in a thick layer of cells at the surface of the hippocampal primordium (Fig. 1A). At E16-P0, reelin mRNA-positive cells were densely packed around the hippocampal fissure, particularly in the outer marginal zone (prospective SLM) (Soriano et al., 1994), which at these stages is densely populated by CR cells (Fig. $1 B$ ). Double-labeled sections positive for calretinin immunoreactivity, a marker of murine CR cells (Soriano et al., 1994; Del Río et al., 1995), confirmed that these intense reelin mRNA-positive cells were indeed CR cells displaying horizontal cell bodies and dendrites (Fig. 1C,D). These data show that reelin mRNA is expressed in CR cells before and during the growth of entorhinal axons into the hippocampus (Supèr and Soriano, 1994).

From E16 onward, a few cells expressing a low level of reelin mRNA were also seen in the inner marginal zone (prospective $\mathrm{SR}$ ) and below the pyramidal layer (prospective SO) (Fig. 1B,C). Double-labeling studies revealed that these neurons were calretinin-negative, although some expressed calbindin (data not shown), a marker for a population of GABAergic pioneer neurons present in these layers (Soriano et al., 1994; Supèr et al., 1998a,b). Thus, in addition to CR cells, reelin is expressed at low levels in a subpopulation of GABA-positive neurons.

reelin mRNA was also expressed in CR cells in layer $\mathrm{I}$ of the entorhinal cortex from E12 onward. In addition, weak hybridization was observed from E18 onward in neurons located in layer II of the entorhinal cortex (Fig. $1 B$ ). Because these neurons are known to project to the dentate gyrus (Steward, 1976; Steward and Scoville, 1976; Swanson and Cowan, 1977; Ruth et al., 1982; Amaral and Witter, 1995), we conclude that reelin mRNA is also expressed in neurons that originate in the entorhino-hippocampal pathway.

During the early postnatal period (P2-P10), the pattern of expression and intensity of labeling in the hippocampal area 

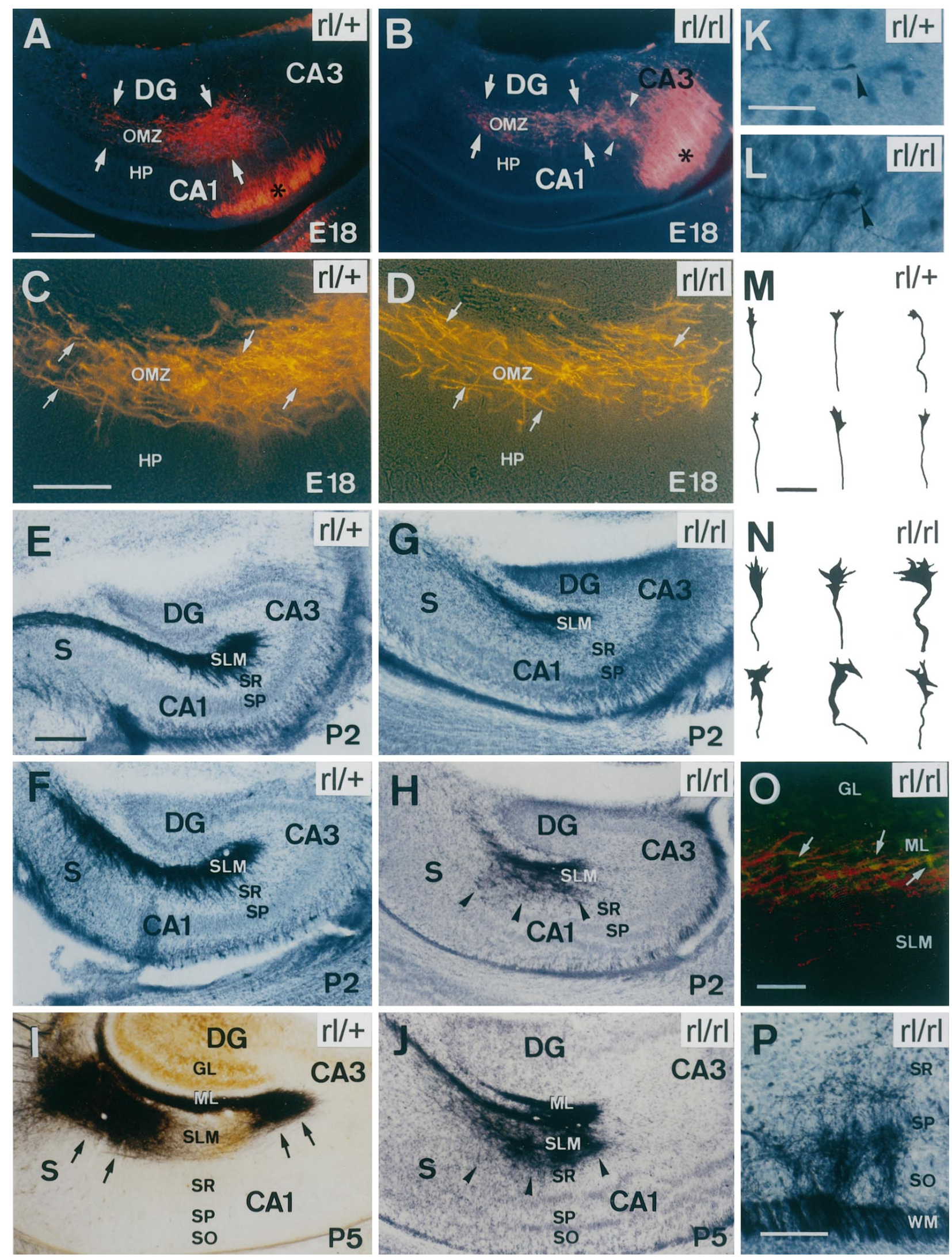

Figure 2. Development of the entorhino-hippocampal pathway in reeler and heterozygous mice. $A-D$, Fluorescence photomicrographs illustrating the pattern of DiI labeling in the hippocampus after an entorhinal injection in $r l /+(A, C)$, and $r l / r l(B, D)$ E18 embryos. $A, r l /+$ embryos exhibit a dense uniform innervation (arrows) restricted to the prospective stratum lacunosum-moleculare [outer marginal zone $(O M Z)$ ], whereas $r l / r l$ embryos $(B)$ show labeled axons in this layer (arrows) as well as misrouted fibers in the inner marginal zone (arrowheads). Labeled fibers can also be seen running through the white matter (asterisk). D, Entorhinal fibers in $r l / r l$ embryos follow rather straight courses within the OMZ (arrows) and (Figure legend continues) 
remained essentially similar. At later stages (P15-P21), the expression of reelin mRNA decreased progressively in both CR cells and GABAergic neurons of the hippocampus (data not shown). In adult mice, few weakly labeled cells were observed in the hippocampus and in the entorhinal cortex (Alcántara et al., 1998).

\section{Reeler mice display abnormalities in the entorhino-hippocampal pathway}

To study the role of Reelin in the formation of the entorhinohippocampal projection in vivo, reeler embryos and postnatal animals were injected in the entorhinal cortex with the lipophilic dye DiI or with biocytin. In mouse embryos, entorhinal afferents reach the hippocampal white matter by E14-E15 (Supèr and Soriano, 1994). In wild-type and heterozygous embryos (E16E18), DiI-labeled entorhinal afferents completely filled the outer marginal zone, where fibers had numerous collaterals and produced dense, uniform innervation restricted to the target layer (Fig. $2 A, C$ ). Injections of DiI in reeler embryos revealed labeled entorhinal axons in the outer marginal zone (Fig. $2 B$ ) that were concentrated in a narrow zone near the hippocampal fissure (especially at dorsal levels; data not shown). These axons followed rather straight courses and had few axon collaterals (Fig. $2 B, D)$. Consistent with this, the density of innervation was always lower in reeler embryos than in wild-type and heterozygous embryos. In addition, in reeler embryos a substantial number of fibers invaded layers other than the marginal zone (the SR and the SP) (Fig. 2B). These observations indicate that Reelin contributes to the targeting of entorhinal axons.

The pattern of entorhinal termination in wild-type and heterozygous animals remained similar between P2 and P5, although the innervation in the SLM became denser at P5, with axons forming elaborate arbors. Similarly, entorhinal afferents, which began to invade the dentate molecular layer (ML) at P2, had already formed a dense innervation at P5. At both stages, entorhinal axons were restricted to the entorhinal termination layers, with virtually no invasion of the underlying layers such as the SR or SO (Figs. 2E, F,I, 3). In contrast, in P2-P5 reeler mice, most entorhinal fibers at dorsal hippocampal levels were densely packed in the outer SLM near the hippocampal fissure, where they formed tight axonal bundles (Figs. $2 G, O, 3$ ). At more ventral hippocampal levels, entorhinal fibers were also packed near the hippocampal fissure, from which numerous fibers descended to innervate deep layers (Figs. 2H,J, 3). These fibers innervated the SLM but were also distributed within the SR, the pyramidal layer, and the SO (Figs. 2H,J, 3). Perhaps the most dramatic abnormality in $r l / r l$ mice was the finding that entorhinal axons running through the alveus (the alvear pathway) (Lorente de Nó, 1934) formed a patch of termination in the SR and SO of the CA2 region (Figs. $2 P, 3$ ), a feature never observed in control mice. In the $r l / r l$ dentate gyrus, entorhinal afferents innervated the OML (Figs. 2J, 3), but misrouted fibers terminating in the inner molecular layer and the hilus were very frequent (data not shown). As at embryonic stages, single fibers in reeler mice displayed fewer axonal branches than those in wild-type and heterozygous animals. Another distinguishing feature of $r l / r l$ entorhinal axons is that they were tipped with very large, complex growth cones with long filopodia and large lamellipodia, which contrasted with the small size of growth cones in control mice (Fig. $2 K-N$ ). Furthermore, the characteristic topographic projections from the medial and lateral entorhinal cortices (see below) began to be recognizable at P5 in $r l /+$ and wild-type animals but not in $r l / r l$ mutant mice (Fig. 2I,J).

At P12 the pattern of entorhinal termination was similar to that in adults, and so both ages will be described together. At these ages, biocytin was selectively injected into the medial and lateral entorhinal areas so that the specific topographic projections from these entorhinal subfields could be analyzed (Amaral and Witter, 1995). Entorhinal injections in wild-type and heterozygous animals resulted in a dense innervation restricted to the SLM in the hippocampus proper. Consistent with previous studies (Steward, 1976; Swanson and Cowan, 1977; Ruth et al., 1982; Amaral and Witter, 1995), injections in the lateral entorhinal cortex defined patches of termination in two subzones of the SLM corresponding to the CA1-subicular interface (data not shown) and the CA3-CA2 region (Fig. 4A). Conversely, medial entorhinal projections innervated the SLM in the subiculum and the CA1 region (Fig. 4C). In reeler mice, lateral entorhinal fibers occupied the SLM uniformly throughout the CA1 and subicular fields, without forming region-specific patches, and with a virtual absence of innervation in the CA3 subfield (Fig. 4B). The innervation of the SLM was narrower in $r l / r l(70 \pm 8 \mu \mathrm{m})$ than in heterozygous mice $(125 \pm 6 \mu \mathrm{m})$.

Injections in the medial entorhinal area in $r l / r l$ mice gave rise to the typical two-patch pattern of termination in the SLM of the CA1 and subiculum (Fig. 4D). In addition, numerous aberrant fibers remained present in the pyramidal layer and SO of the CA2-CA1 subfields (Fig. 4D). Moreover, after injections in the lateral and medial entorhinal cortices there were many axons in

\footnotetext{
have fewer collaterals than $r l /+$ embryos $(C) . E-J$, Photomicrographs illustrating the distribution of entorhinal afferents labeled after biocytin injections in the entorhinal cortex at $\mathrm{P} 2$ and $\mathrm{P} 5$ in heterozygous $(r l /+)$ and reeler $(r l / r l)$ mice. Sections from $\mathrm{P} 2$ mice at rostral $(E, G)$ and caudal levels $(F, H)$ are shown. In heterozygous mice both at rostral and caudal levels, at P2 $(E, F)$ entorhinal fibers innervate the entire thickness of the stratum lacunosum-moleculare $(S L M)$. G, Entorhinal fibers in $r l / r l$ mice, in contrast, pack densely near the hippocampal fissure at rostral levels. At caudal levels $(H)$ entorhinal fibers appear packed near the hippocampal fissure, but many axons descend toward lower aspects of the stratum lacunosum-moleculare and to the stratum radiatum (SR) (arrowheads). At P5 (I), lateral entorhinal axons in the hippocampus proper innervate exclusively the stratum lacunosum-moleculare, when the characteristic patchy distribution of axons in the CA3 and CA1 subicular border (arrows) begins to be visible. In addition, fibers innervate the molecular layer $(M L)$ of the dentate gyrus $(D G) . J$, In P5 rl/rl mice, most entorhino-hippocampal fibers are still packed in the vicinity of the hippocampal fissure, at the molecular layer as well as the neighboring stratum lacunosum-moleculare, although abundant fibers are also present in the inner portion of the stratum lacunosum-moleculare and in the stratum radiatum (arrowheads). $K, L$, High-magnification photomicrographs illustrating growth cones in the stratum lacunosum-moleculare of P5 heterozygous $(K)$ and P2 reeler $(L)$ mice. $M, N$, Camera lucida drawings of axonal growth cones in the stratum lacunosum-moleculare from P2 heterozygous $(M)$ and reeler $(N)$ mice. Growth cones of mutant mice are larger, and display numerous filopodia and lamellipodia, compared with $r l /+$ animals. $O$, Confocal image of the $r l / r l$ hippocampus at P2 illustrating bundles of entorhinal fibers $($ red $)$ in the stratum lacunosum-moleculare overlapping with Cajal-Retzius cells ( green) (arrows). P, Photomicrograph of CA3-CA2 hippocampal subfields of a reeler mouse injected with biocytin in the entorhinal cortex at P5, illustrating abundant misrouted fibers in the stratum radiatum, stratum pyramidale $(S P)$, and stratum oriens $(S O)$. $C A 1, C A 2, C A 3$, Hippocampal areas; $G L$, granule layer; $H P$, hippocampal primordium; $W M$, white matter. $A, B$, sections counterstained with bisbenzimide; $E-H, J-L, P$, sections counterstained with Nissl staining; $I, O$, sections processed for calretinin immunostaining. Scale bars: $A, B, E-J, 200 \mu \mathrm{m} ; C, D, P, 100 \mu \mathrm{m} ; K, L, 25 \mu \mathrm{m} ; M, N, 10 \mu \mathrm{m} ; O, 50 \mu \mathrm{m}$.
} 


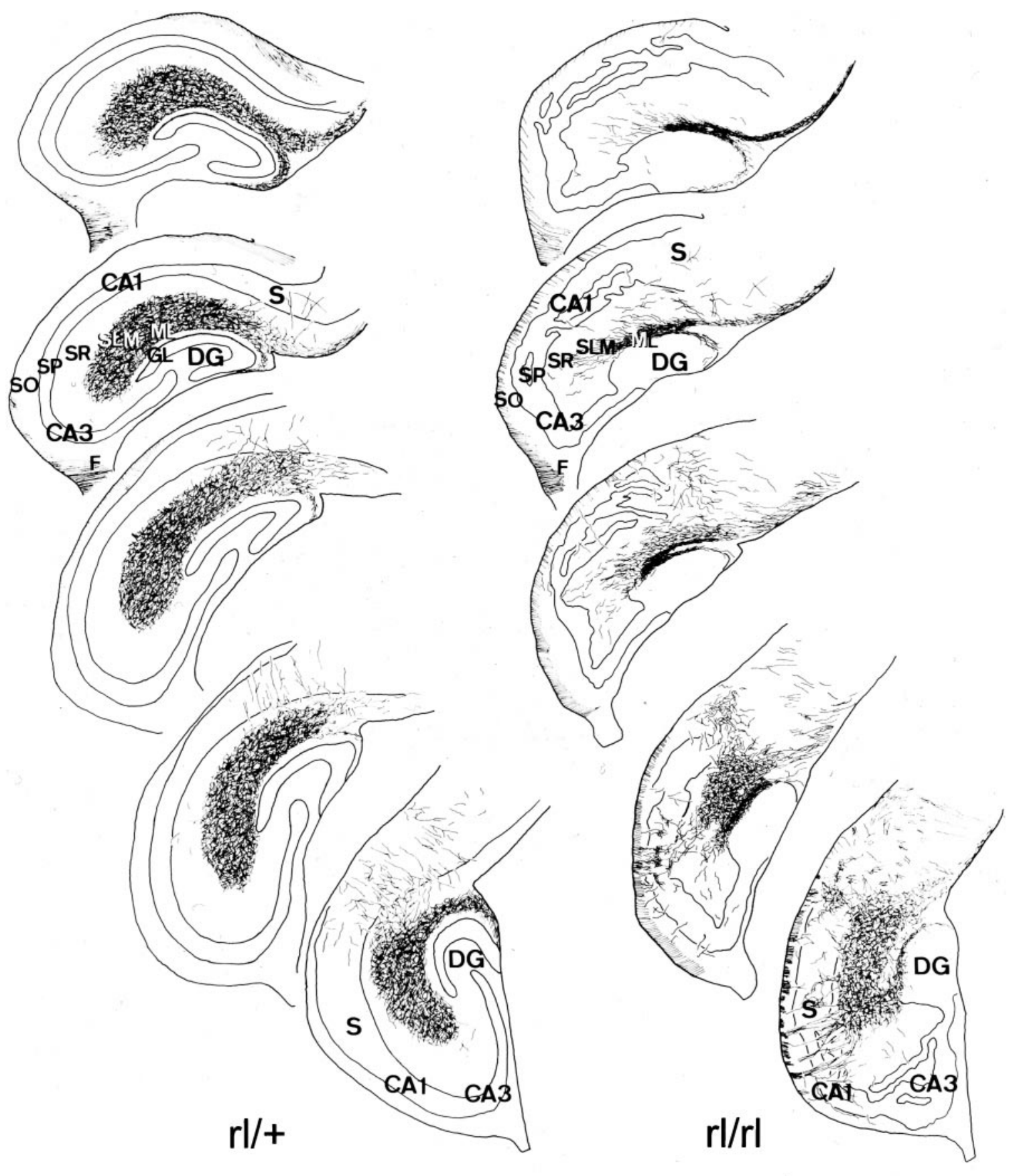

Figure 3. Camera lucida drawings illustrating the distribution and spatial arrangement of biocytin-traced entorhinal fibers in the hippocampus of heterozygous $(r l /+)$ and reeler $(r l / r l)$ mice at P5. Coronal sections are ordered from rostral (top) to caudal (bottom). Note the large numbers of misrouted fibers in the $r l / r l$ hippocampus. Hippocampal layers and subfields are indicated by conventions used in Figure 2. F, Fimbria. Scale bar, $500 \mu \mathrm{m}$.

inappropriate layers, including the $\mathrm{SR}, \mathrm{SO}$, and pyramidal layer. These aberrant projections were more frequent at P12 than in the adult.

In the dentate gyrus of $+/+$ and $r l /+$ mice, lateral entorhinal projections terminated in the OML, whereas medial entorhinal fibers were restricted to the middle molecular layer (MML) (Fig. $4 E, G, I, K)$. In reeler mice, axons arising from the lateral entorhinal area terminated in an outer band near the hippocampal fissure, which was narrower than in control mice. Medial entorhinal fibers terminated in the MML. However, afferents arriving from both entorhinal subfields gave rise to aberrant fibers that terminated in inappropriate layers of the dentate gyrus, such as the hilus (Fig. 4F,H,J,L).

This in vivo analysis indicates that reeler entorhinal fibers show aberrant trajectories and termination patterns as well as decreased fiber growth, which appear to be partially corrected as development progresses. Similarly, although the region-specific topographic projections from the lateral and medial entorhinal areas are preserved to a certain extent in reeler mice, they also show abnormal patterns of termination. 


\section{Entorhinal axons in reeler mice transiently exhibit reduced axonal arbors}

To confirm these findings, a quantitative analysis was undertaken on single entorhinal axons present in the CA1 field and in the dentate gyrus. In the CA1 field, reeler entorhinal fibers had a reduced branching index at P2 and more so at P5 (69.7\% less) (Fig. 5B). At this age, entorhino-dentate axons also had fewer axon collaterals in reeler mice than in heterozygous animals (51.2\% less). At P12 the differences between reeler and heterozygous mice disappeared in the dentate gyrus, whereas they persisted in the CA1 field. The branching index in adult mutant mice was similar to that in $r l /+$ mice, in both hippocampal regions.

Entorhinal axon side branches in reeler mice were slightly, but significantly, shorter than in heterozygous mice at all stages examined, except at P5 in the SLM (Fig. 5C). The lack of a significant difference at P5 may be because this is the period of greatest side branch formation in heterozygous mice (Fig. 5B), and thus most newly formed collaterals may be short. These findings indicate that Reelin promotes the branching and extension of developing entorhinal axons in vivo.

\section{Reeler mutant mice show altered hippocampal synaptogenesis}

To determine whether Reelin influences the sequence of synaptogenesis, we first counted the number of axonal varicosities in biocytin-labeled entorhinal fibers (Fig. 5D). Both in the dentate gyrus and in the CA1 region, axons of reeler mice at P2-P5 had a lower density (34-52\% less) of axonal varicosities than heterozygous mice. These differences were reduced at P12, but they were still detectable in adult mutant mice (10-28\% reduction). These data suggest that Reelin participates in the hippocampal synaptogenesis.

To examine the role of Reelin in early synaptogenesis, biocytin was injected into the entorhinal cortex, and labeled axons were examined by electron microscopy. Identified entorhinohippocampal afferents established morphologically mature synaptic contacts at early postnatal stages (P2-P5) in both reeler and heterozygous animals (Fig. 6C,D). In both groups the labeled entorhinal boutons displayed synaptic vesicles clustered near the active synaptic zones, with typical presynaptic and postsynaptic densities. Synaptic contacts were asymmetric, and postsynaptic targets included dendritic shafts and spines. Moreover, tight axonal bundles were frequently observed in the SLM of $r l / r l$ mice (Fig. $6 E$ ), whereas this feature was rarely found in heterozygous mice.

To estimate the density of entorhinal synapses we quantified the number of synaptic contacts observed in the SLM and OML of the dentate gyrus (Figs. $6 A, B, 7$ ). At P2-P5 we found a $26-53 \%$ reduction in the numbers of synaptic contacts in the SLM and OML of reeler mice, which was more marked at P2. In contrast, no significant differences were observed in the length of the synaptic contacts between the two groups (e.g., at P2, in the SLM, $0.287 \pm 0.013$ and $0.333 \pm 0.018 \mu \mathrm{m}$ in $r l / r l$ and $r l /+$ mice, respectively). These findings indicate that Reelin is involved in the regulation of synaptogenesis in the developing hippocampus.

\section{Reelin produced in the target region is responsible for fiber abnormalities in reeler mutant mice}

Because reelin transcripts are expressed in both the hippocampus and the entorhinal area (including entorhino-hippocampal neurons) (Fig. $1 B$ ), the fiber abnormalities reported in $r l / r l$ mice could be attributable to the lack of Reelin in either the target region or at the site of axonal origin. Also, the mispositioning of neurons in the entorhinal cortex of reeler mice may influence the pattern of entorhino-hippocampal innervation. To discern among these possibilities we prepared mixed organotypic slice co-cultures obtained from reeler and heterozygous newborn mice. After 7-15 DIV, homogenetic co-cultures $\left(\mathrm{E}^{+/+} / \mathrm{H}^{+/+}, \mathrm{E}^{r l /+} / \mathrm{H}^{r l /+}, \mathrm{E}^{r l / r l} /\right.$ $\mathrm{H}^{r l / r l}$ ) displayed patterns of entorhinal innervation similar to those described in vivo (Fig. $8 A, B$ ). Thus, in $+/+$ and $r l /+$ co-cultures entorhino-hippocampal fibers formed a dense innervation that completely filled the SLM and OML (Fig. 8A). Fibers displayed numerous axonal varicosities and axon collaterals (Table 1, Fig. 9) and were observed only rarely in inappropriate layers.

The pattern of innervation in $r l / r l$ co-cultures was quite different. These co-cultures displayed a compacted entorhinal projection to the dentate gyrus, near the hippocampal fissure, with axons well collateralized and with numerous varicosities. The innervation of the SLM, in contrast, was very scarce, with fibers occupying a narrow zone of termination and giving rise to a reduced density of innervation (Table 1, Figs. 8B, 9). Entorhinal fibers in the SLM showed straight courses and few axonal side branches. In addition, there were many aberrant entorhinal fibers in the hilus, the SR, and the pyramidal layer (data not shown). Quantitative analyses showed a lower branching index of entorhinal fibers in the SLM, but not in the ML, than in $r l /+$ co-cultures (Fig. 9). Thus, the abnormalities of the entorhino-hippocampal projection in reeler slice co-cultures are reminiscent of those in reeler mice in vivo. Because entorhino-hippocampal fibers are severed during the preparation of the slice cultures, these results also indicate that Reelin plays a similar role both in developing and in regenerating axotomized entorhino-hippocampal axons.

When heterozygous entorhinal slices were co-cultured with reeler hippocampi, both the pattern of innervation and the characteristics of single axons were identical to those of reeler cocultures (Table 1). Thus, the entorhinal projection matched the reeler-like pattern described above, and single axons showed less collateral branching in the SLM (Figs. 8D, 9). In contrast, cocultures of reeler entorhinal cortex with heterozygous hippocampus resulted in normal patterns of entorhinal innervation (Table 1, Fig. 8C) and axonal branching (Fig. 9). In neither of the co-culture combinations did we observe major differences when the slices were cultured for 7 or 15 DIV, except that the density of innervation increased after longer incubation. These in vitro experiments indicate that the abnormalities of the entorhinohippocampal projection in reeler mice are caused by the lack of Reelin in the target hippocampal region.

\section{DISCUSSION}

\section{Reelin and the formation of layer-specific and topographic connections in the hippocampus}

A distinguishing feature of developing hippocampal connections is that ingrowing afferents invade the appropriate target layer when they reach the hippocampus. Thus, entorhinal fibers invade the SLM from the beginning, with no growth into other hippocampal layers, and commissural/associational afferents terminate specifically in the SR and SO from E18 onward (Supèr and Soriano, 1994; Supèr et al., 1998a,b). These findings, together with a recent study showing that entorhinal cells selectively adhere to their termination layers in the hippocampus (Förster et al., 1998), suggest the presence of layer-specific positional cues that target particular hippocampal afferents. In a previous study we showed that CR cells, a special class of pioneer neuron (Soriano et al., 1994; Del Río et al., 1995; Supèr et al., 1998a), 

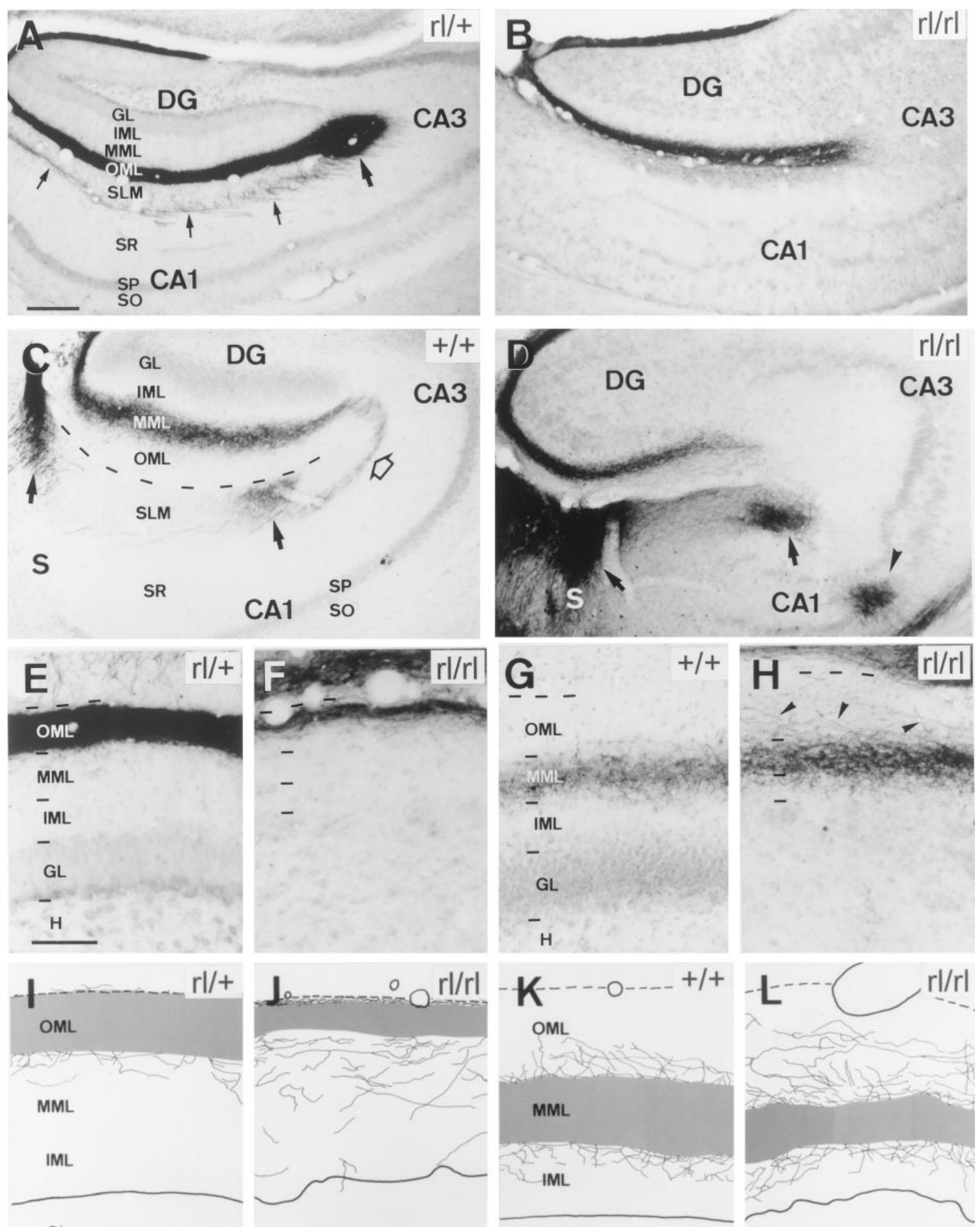

GL

GL

H

$\mathrm{H}$

Figure 4. Pattern of entorhino-hippocampal projection in adult reeler $(r l / r l)$ and heterozygous $(r l /+)$ mice. $A, B$, Photomicrographs illustrating the pattern of entorhino-hippocampal innervation after biocytin injection in the lateral entorhinal cortex. $A$, Injections in the lateral entorhinal cortex in $r l /+$ mice yield a dense patch of fibers in the stratum lacunosum-moleculare (SLM) of the CA3 region (large arrow) and the subicular-CA1 interface (data not shown). Some fibers are also observed in CA1 (small arrows). In the dentate gyrus $(D G)$, axons are restricted to the outer third of the molecular layer $(O M L) . B$, In $r l / r l$ mice, lateral entorhinal projections result in a narrow band of fibers in the stratum lacunosum-moleculare (Figure legend continues) 
A
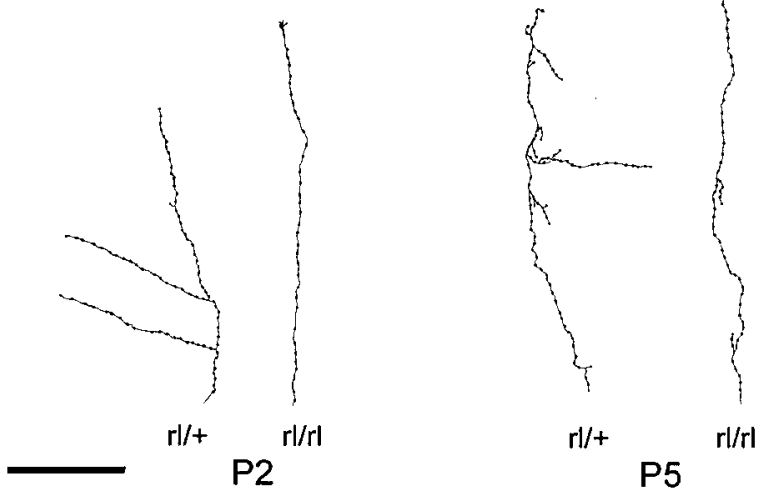

B

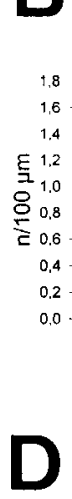

Branching index

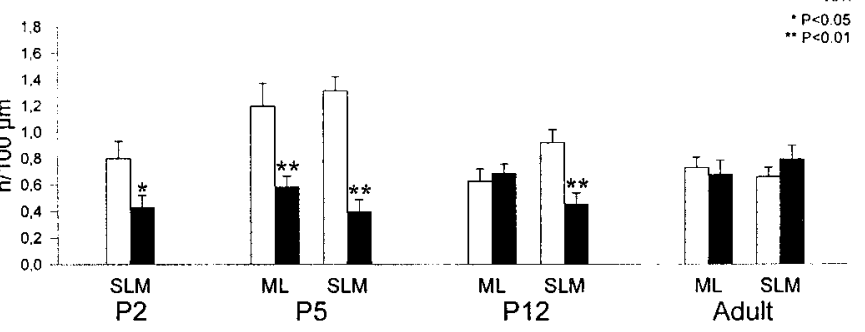

D

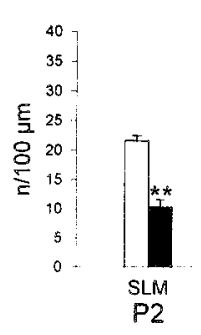

Density of axonal varicosities

have an essential role in the ingrowth and targeting of entorhinal afferents (Del Río et al., 1997). A crucial role for these neurons is supported by experiments in which ectopically placed CR cells perturb the targeting of entorhino-hippocampal fibers (J. A. Del
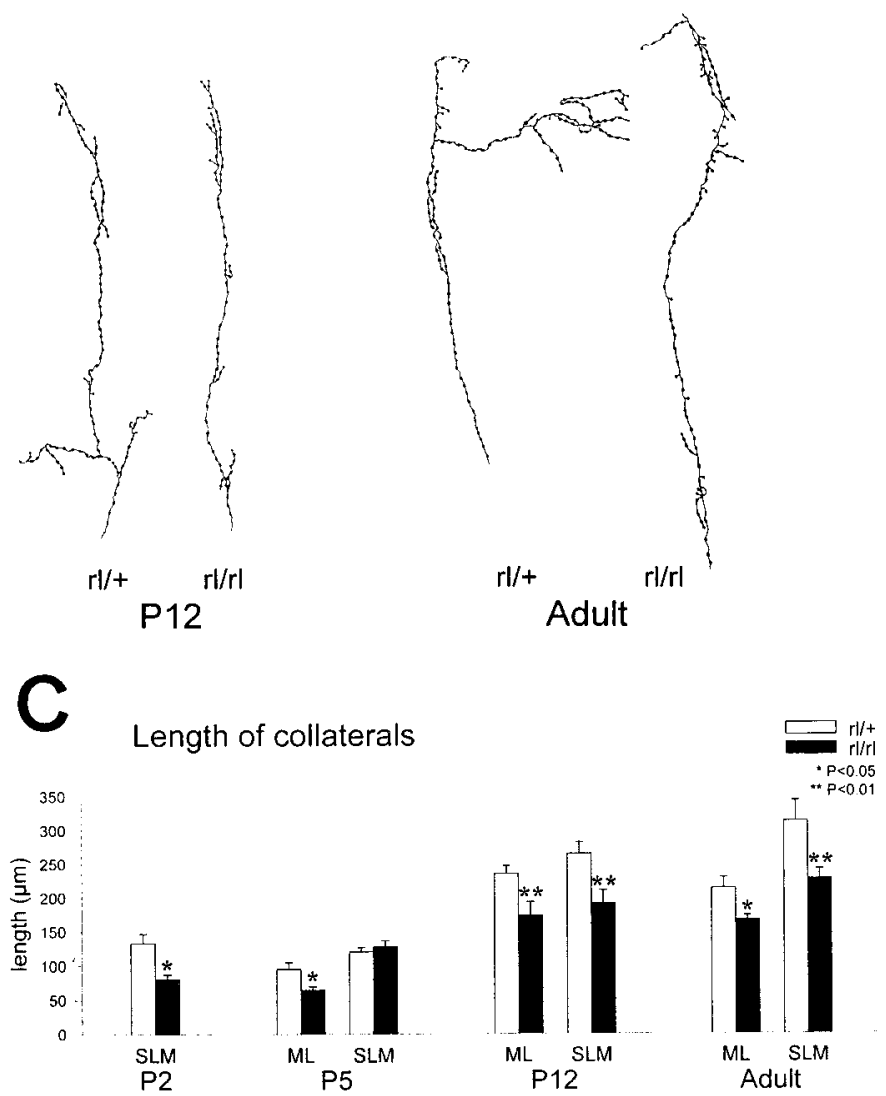

Figure 5. Analysis of single entorhino-hippocampal axons in reeler mice. $A$, Camera lucida drawings of single axons in the stratum lacunosummoleculare of heterozygous $(r l /+)$ and reeler $(r l / r l)$ mice at P2, P5, P12, and adult. A robust difference in axonal arbor complexities can be observed between $r l /+$ and $r l / r l$ fibers, in which $r l / r l$ fibers are less elaborated. $B-D$, Quantification of the branching index (number of axonal branching points per $100 \mu \mathrm{m}$ ), length of axon collaterals, and density of axon terminals (number of boutons per $100 \mu \mathrm{m}$ ) in heterozygous (open bars) and reeler mice ( filled bars) at P2, P5, P12, and adult. Data are mean \pm SEM. Statistically significant differences are indicated $\left({ }^{*} p<0.05,{ }^{*} p<\right.$ 0.01; ANOVA, LSD test). Scale bar, $100 \mu \mathrm{m}$.

Río, unpublished observations). These studies prompted the present analysis of the function of Reelin, an extracellular protein highly expressed in CR cells (D'Arcangelo et al., 1995, 1997; Alcántara et al., 1998).

of the CA1 region and in the outer molecular layer of the dentate gyrus, near the hippocampal fissure. Note that the characteristic patch of termination in the stratum lacunosum-moleculare of the $\mathrm{CA} 3$ region is not observed. $C, D$, Pattern of entorhino-hippocampal innervation after medial entorhinal injections of biocytin. In $(C)+/+$ and $r l /+$ mice, entorhinal axons innervate two patches in the subiculum $(S)$ and in the stratum lacunosum-moleculare of the proximal CA1 region (arrows), in continuation with a narrow band of fibers in the lower stratum lacunosum-moleculare of the CA3 region (open arrow). In the dentate gyrus, fibers are restricted to the middle molecular layer $(M M L)$. $D$, Injections in $r / / r l$ mice show two patches of termination in the stratum lacunosum-moleculare of the CA1 region and subiculum (arrows), reminiscent of those in wild-type animals. In addition, numerous aberrant fibers are present in the stratum pyramidale $(S P)$ and stratum oriens $(S O)$ of the CA2 subfield (arrowhead). The pattern of medial innervation in the dentate gyrus involves the middle molecular layer. $E-H$, Photomicrographs of the dentate gyrus showing the pattern of termination of lateral and medial entorhinal projections in $(E) r l /+$ and $(G)+/+$ mice compared with $(F, H) r l / r l$ mice. In heterozygous $(E)$ and wild-type mice (data not shown), the lateral entorhinal afferents occupy the outer third of the molecular layer, whereas in reeler mice $(F)$ the projection to the outer molecular layer is restricted to the vicinity of the hippocampal fissure, with numerous fibers invading ectopic layers. Medial entorhinal axons from wild-type ( $G$ ) are restricted to the middle molecular layer; in reeler mutants $(H)$, fibers mostly project to the middle molecular layer, although numerous misrouted axons appear in the outer molecular layer, inner molecular layer $(I M L)$, and hilus $(H)$ (arrowheads). $I-L$, Camera lucida drawings illustrating the laminar distribution of lateral $(I, J)$ and medial $(K, L)$ entorhinal fibers in the dentate gyrus. Note increased numbers of misrouted fibers in $r l / r l$ mice. $C A 1$, $C A 2$, $C A 3$, Hippocampal areas; $G L$, granule layer; $H$, hilus; $S R$, stratum radiatum. Scale bars: $A-D, 200 \mu \mathrm{m} ; E-L, 100 \mu \mathrm{m}$. 

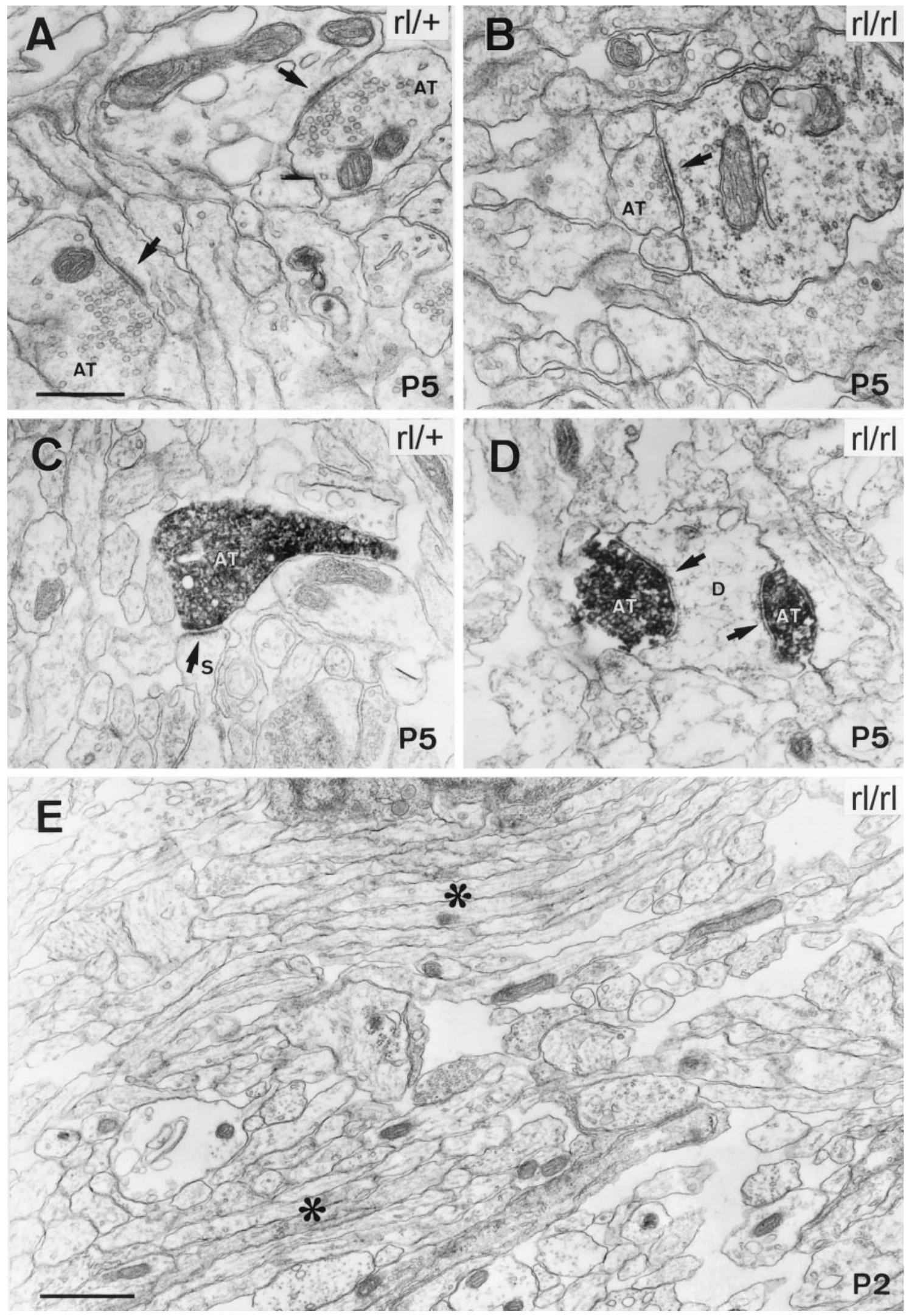

Figure 6. Ultrastructural features of synaptic contacts in the $r l /+$ and $r l / r l$ mice. $A, B$, Electron micrographs illustrating the characteristics of synaptic terminals in the stratum lacunosum-moleculare in $r l /+$ and $r l / r l$ P5 mice. $A$, In both groups axon terminals exhibit well developed synaptic contacts (arrows) and abundance of synaptic vesicles. $C, D$, Electron micrographs showing biocytin-traced, entorhinal axon terminals $(A T)$ in synaptic contact (arrows) with a postsynaptic spine $(S)$ and a dendritic shaft $(D)$ in $r l /+$ and $r l / r l$ mice at P5. E, Low-power electron micrograph illustrating tight bundles of fibers (asterisks) near the hippocampal fissure in $r l / r l$ mice at P2. Scale bars: $A-D, 0.5 \mu \mathrm{m} ; E, 1 \mu \mathrm{m}$. 


\section{Density of synaptic contacts}

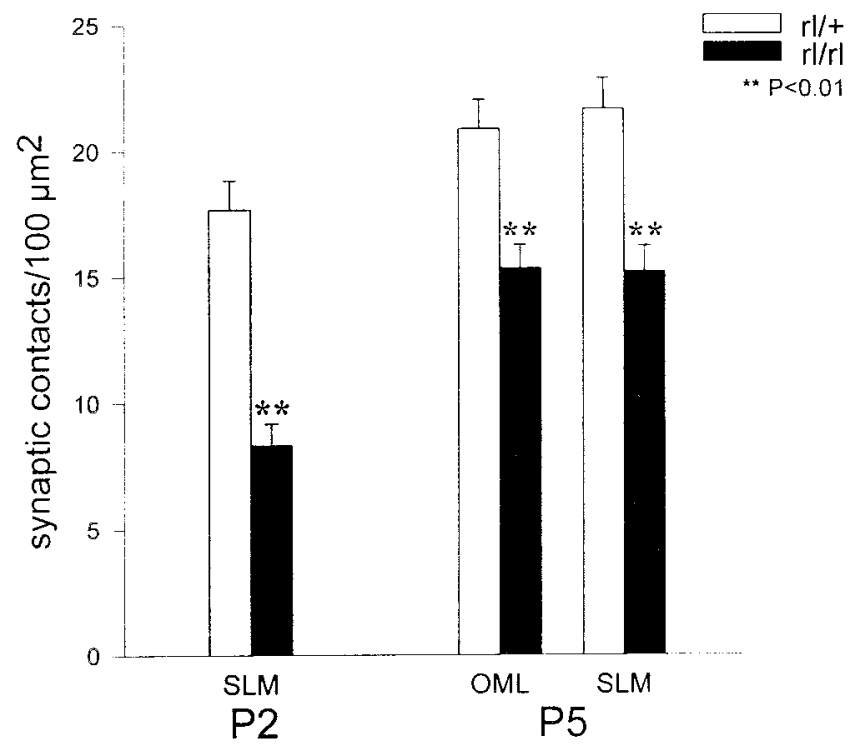

Figure 7. Density of synaptic contacts present in the target layers $(S L M$ and $O M L$ ) of the entorhino-hippocampal projection at P2 and P5. Values $\left(n / 100 \mu \mathrm{m}^{2}\right.$; mean $\left.\pm \mathrm{SEM}\right)$ are significantly lower in $r l / r l$ than in $r l /+$ animals. Significant differences are indicated $\left({ }^{* *} p<0.01\right.$; ANOVA, LSD test).
The present analyses of reeler mutant mice show that the entorhino-hippocampal pathway is formed in the absence of Reelin, indicating that this protein is not essential for the ingrowth of entorhinal axons to the hippocampus. Thus, in accordance with current views on axonal guidance (Goodman, 1996; Tessier-Lavigne and Goodman, 1996), the early trajectory of entorhinal fibers toward the hippocampus may be mediated by long-range molecular cues, including members of the Netrin and Semaphorin families (Chédotal et al., 1998). The present study also shows that, to a certain extent, entorhinal fibers in reeler mice terminate in the appropriate target layer (but see below). This indicates that, in addition to Reelin, other positional cues may determine the guidance of entorhinal afferents toward their specific termination layers [see also Förster et al. (1998)]. Some of the factors that provide such guidance in other brain regions are members of the ephrin and semaphorin families (Cheng et al., 1995; Drescher et al., 1995; Messersmith et al., 1995; Culotti and Kolodkin, 1996; Brennan et al., 1997; Wang and Anderson, 1997). Indeed, we have recently shown that several secreted Semaphorins and Neuropilin receptors are expressed in the developing hippocampal formation, and that Semaphorin III and IV have strong repulsive effects on both entorhinal and hippocampal axons (Chédotal et al., 1998).

In agreement with earlier studies (Stanfield et al., 1979), we found that the general topography of hippocampal connections is
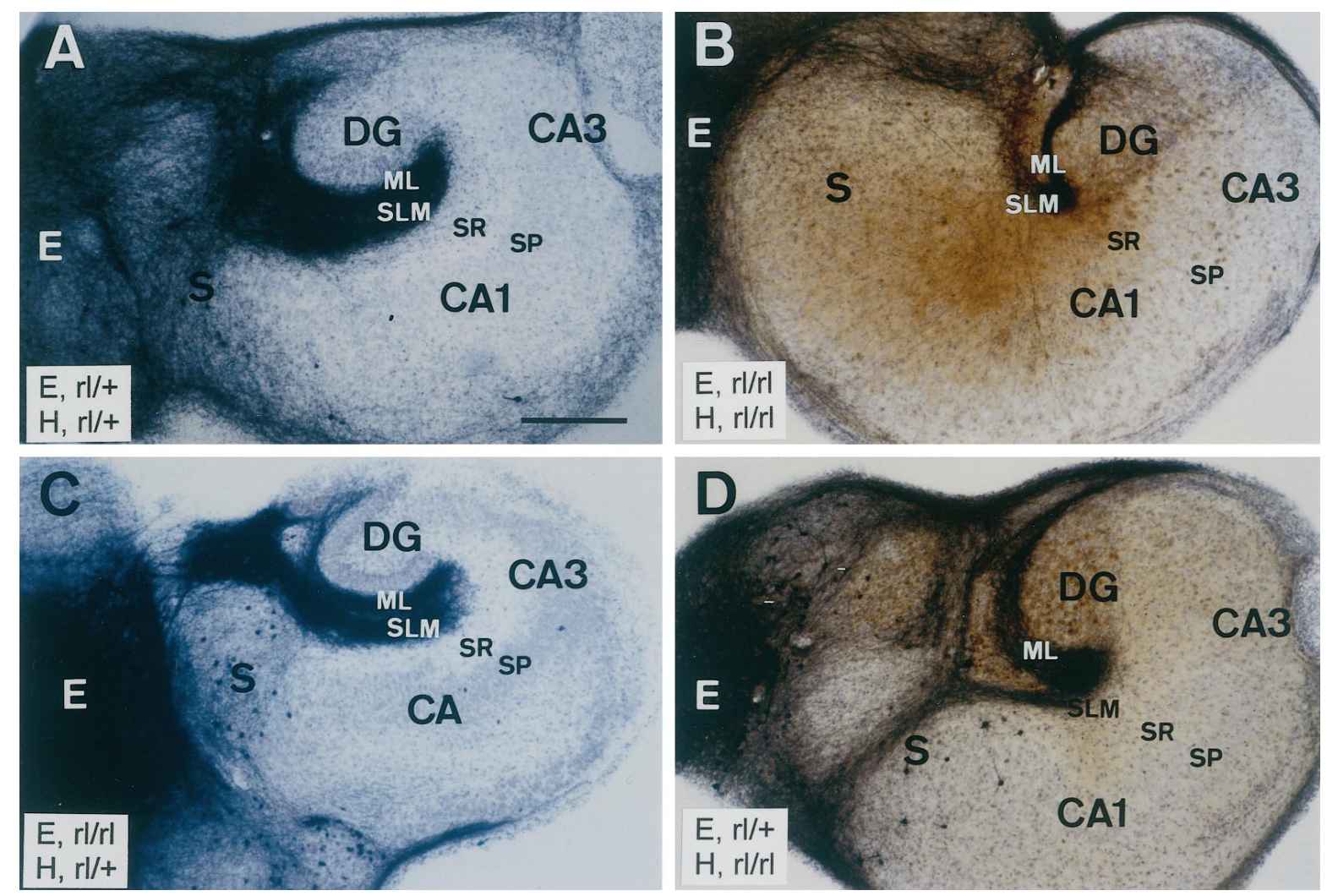

Figure 8. Development of the entorhino-hippocampal pathway in reeler organotypic slice co-cultures. After 7-15 DIV, the entorhino-hippocampal pathway was traced with a biocytin injection in the entorhinal cortex. $A, B$, Examples of co-cultures of entorhinal cortex $(E)$ and hippocampus $(H)$ prepared from heterozygous $(r l /+)(A)$ and reeler $(r l / r l)(B)$ mice after 7 DIV. Whereas in $\mathrm{E}^{r l /+} / \mathrm{H}^{r l /+}$ co-cultures entorhinal afferents completely filled the stratum lacunosum-moleculare $(S L M)$ and the molecular layer $(M L), \mathrm{E}^{r l / r l} / \mathrm{H}^{r l / r l}$ co-cultures displayed very scarce innervation of the stratum lacunosum-moleculare, and a compacted projection to the dentate gyrus $(D G)$ near the hippocampal fissure. $C, D$, Examples of mixed organotypic co-cultures. In co-cultures of $r l / r l$ entorhinal cortex and $r l /+$ hippocampus, the pattern of entorhinal projection is reminiscent of that observed in heterozygous homogenetic co-cultures, whereas in co-cultures with $r l / r l$ hippocampus and $r l /+$ entorhinal cortex, the pattern of projection is reminiscent of that of reeler homogenetic co-cultures. $A-D$, Co-cultures counterstained with Nissl; in $B, D$, they are processed for the immunodetection of calretinin. $C A 1, C A 3$, Hippocampal areas; $S$, subiculum; $S R$, stratum radiatum. Scale bar (shown in $A$ for $A-D$ ): $300 \mu \mathrm{m}$. 


\begin{tabular}{|c|c|c|c|c|c|c|}
\hline \multirow{2}{*}{$\begin{array}{l}\text { Culture } \\
\text { condition }\end{array}$} & \multicolumn{6}{|c|}{ Number of co-cultures } \\
\hline & wt & $\mathrm{wt}(-)$ & $\mathrm{wt} / r l$ & $r l(-)$ & $r l$ & Total \\
\hline \multicolumn{7}{|l|}{7 DIV } \\
\hline $\mathrm{E}^{+/+} / \mathrm{H}^{+/+}$ & 12 & 3 & 0 & 0 & 0 & 15 \\
\hline $\mathrm{E}^{r l /+} / \mathrm{H}^{r l /+}$ & 11 & 1 & 0 & 0 & 0 & 12 \\
\hline $\mathrm{E}^{r l / r l} / \mathrm{H}^{r l / r l}$ & 0 & 0 & 0 & 6 & 13 & 19 \\
\hline $\mathrm{E}^{r l / r l} / \mathrm{H}^{r l /+}$ & 30 & 11 & 0 & 0 & 0 & 41 \\
\hline $\mathrm{E}^{r l /+} / \mathrm{H}^{r l / r l}$ & 0 & 0 & 0 & 13 & 17 & 30 \\
\hline \multicolumn{7}{|l|}{15 DIV } \\
\hline $\mathrm{E}^{+/+} / \mathrm{H}^{+/+}$ & 12 & 0 & 0 & 0 & 0 & 12 \\
\hline $\mathrm{E}^{r l /+} / \mathrm{H}^{r l /+}$ & 13 & 0 & 0 & 0 & 0 & 13 \\
\hline $\mathrm{E}^{r l / r l} / \mathrm{H}^{r l / r l}$ & 0 & 0 & 0 & 3 & 18 & 21 \\
\hline $\mathrm{E}^{r l / r l} / \mathrm{H}^{r l /+}$ & 14 & 1 & 0 & 0 & 0 & 15 \\
\hline $\mathrm{E}^{r l /+} / \mathrm{H}^{r l / r l}$ & 0 & 0 & 0 & 3 & 11 & 14 \\
\hline
\end{tabular}

$\overline{\text { Entorhino-hippocampal co-cultures were prepared from }+/+, r l /+, \text { and } r l / r l \text { tissue, }}$ and the entorhino-hippocampal pathway was traced with biocytin and fixed after 7 and 15 DIV. Co-cultures were classified according to the pattern of entorhinal innervation in the SLM/ML. wt, Wild-type pattern: entorhinal fibers target to the stratum lacunosum-moleculare and molecular layer occupying the entire thickness of these layers, with a high density of innervation ( $>10$ fibers/75 $\mu \mathrm{m})$, and single fibers exhibit abundant collateral branches and axonal varicosities. wt - , Scarce wild-type pattern: similar to the pattern described in wt, but with a decreased density of innervation $(<10$ fibers/ $75 \mu \mathrm{m})$. rl, reeler-like pattern: the entorhinal termination in the stratum lacunosum-moleculare is very scarce and restricted to the vicinity of the hippocampal fissure, with fibers following straight courses and exhibiting very few axonal collaterals and varicosities; projection to the dentate gyrus appears densely packed in the outer molecular layer $(>20$ fibers $/ 75 \mu \mathrm{m})$, with abundance of collateral branches and axonal boutons; presence of misrouted fibers in stratum radiatum and stratum pyramidale of the CA1-CA3 regions and in the hilus. $r l-$, Scarce reeler-like pattern: similar to the pattern described in $r l$, with a decreased density of innervation $(<10$ fibers $/ 75 \mu \mathrm{m})$ in the dentate gyrus. wt/rl, Wild-type/ reeler pattern: co-cultures showing intermediate $(r l)$ or $(\mathrm{wt})$ pattern of termination.

preserved in reeler mice. However, there are a number of marked abnormalities, which include a dramatic increase in ectopic fibers innervating inappropriate layers and the formation of aberrant projections from the medial entorhinal cortex to the SR and SO of the CA2 region. In addition, the lateral entorhinal projection to the SLM of the CA3 region is clearly absent in these mutant mice. The CR-50 blocking studies on wild-type co-cultures, demonstrating a reeler-like axonal phenotype without disruption of hippocampal layers, indicate that the fiber abnormalities in reeler mice are unlikely to be caused by the mispositioning of hippocampal neurons (Del Río et al., 1997). Thus, there are at least two possible explanations for these abnormalities: (1) Reelin contributes to the layer-specific and topographic targeting of entorhinal axons via direct interaction with developing fibers, or (2) extracellular Reelin facilitates the mechanism of action of other, crucial factors that provide positional information. Although further studies are clearly needed to discern between these possibilities, we favor a direct interaction of Reelin with growing axons, as suggested by our finding of abnormally large, complex growth cones in reeler mice.

\section{Reelin and the elaboration of axonal arbors}

One remarkable finding of this study is that, in the absence of Reelin, entorhinal axons form tight bundles and have decreased axonal branching and elongation of side collaterals. Although Reelin has been proposed to provide a stop signal for migrating neurons (Ogawa et al., 1995; D'Arcangelo et al., 1997), the present study on the formation of hippocampal connections in reeler mice does not support a role for Reelin as a repulsive signal for developing entorhinal axons. On the contrary, extracellular
Reelin appears to favor the growth, extension, and branching of entorhinal axons in their termination layers. It remains to be established whether Reelin only provides a permissive substrate for axon elongation or whether it signals the formation and growth of collateral branches.

Other molecules, including $\mathrm{Ng}-\mathrm{CAM}$, fasciclin II, polysialic acid, ephrins, semaphorins, receptor protein tyrosine phosphatases, and neurotrophins, contribute to axonal bundling, defasciculation, and axonal branching (Tang et al., 1992; Lin et al., 1994; Cabelli et al., 1995; Cohen-Cory and Fraser, 1995; Matthes et al., 1995; Püschel et al., 1995; Stoeckli and Landmesser, 1995; Winslow et al., 1995; Desai et al., 1996; Fujisawa et al., 1997). This suggests that there may be redundancy of signals regulating these processes, which may explain the finding that some fiber abnormalities in reeler mice are more dramatic at perinatal stages than in the adult. For instance, the partial recovery of fiber abnormalities in reeler mice from P12 onward may be caused, at least in part, by the action of neurotrophins BDNF and NT-3, which also influence the branching of hippocampal afferents at comparable stages (Martínez et al., 1998).

\section{Reelin and synaptogenesis of hippocampal connections}

Although reeler entorhinal axons appear to form normal axonal varicosities with synaptic vesicles and morphologically mature synaptic contacts, their number is dramatically reduced. The reduced number of synaptic contacts might result simply from the decreased branching and maturation of single entorhinal axons in these mutant mice. However, the observation that reeler entorhinal fibers have fewer axonal varicosities along their length points to a direct effect of Reelin in the formation of synapses. Little is known about the molecular factors that regulate synapse formation and the number of synaptic inputs. Very recently, it has been proposed that neurotrophins and $\mathrm{N}$-cadherins may regulate the density of synaptic innervation (Snider and Litchman, 1996; Causing et al., 1997; Inoue and Sanes, 1997; Martínez et al., 1998). Thus, like other processes contributing to the development of neuronal connections, the formation of synapses appears to be multifactorial and dependent on a combination of factors.

\section{Reelin, an extracellular protein involved in neuronal migration and axonal growth}

Recent data have shown that the same factors may play a role in both neuronal migration and axonal growth. For example, netrin-1 exerts chemoattractive or chemorepulsive effects on both developing axons and migrating neurons (Serafini et al., 1996; Wadsworth et al., 1996). The strong abnormalities apparent in reeler mice demonstrates that Reelin plays a role in neuronal migration (D'Arcangelo et al., 1995; Ogawa et al., 1995; Goffinet, 1997). However, Reelin is a large extracellular protein with distinct domains, which suggests that it may be involved in different processes (D'Arcangelo et al., 1995). Here we provide evidence that Reelin participates in the targeting of topographic connections, in the branching and growth of single fibers, and in the synaptogenesis of hippocampal afferents. The manner in which Reelin contributes to these developmental processes is unknown, but the growth of entorhinal axons onto a Reelin-rich termination zone might suggest molecular interactions between target-derived Reelin and putative Reelin-binding proteins present in developing axons. Recent studies have shown that mutations in genes encoding signal transduction-associated proteins, including the $c d k 5, p 35$, and $m d a b 1$ genes, lead to deficits in 
A

\section{Branching index $(\mathrm{ML})$}
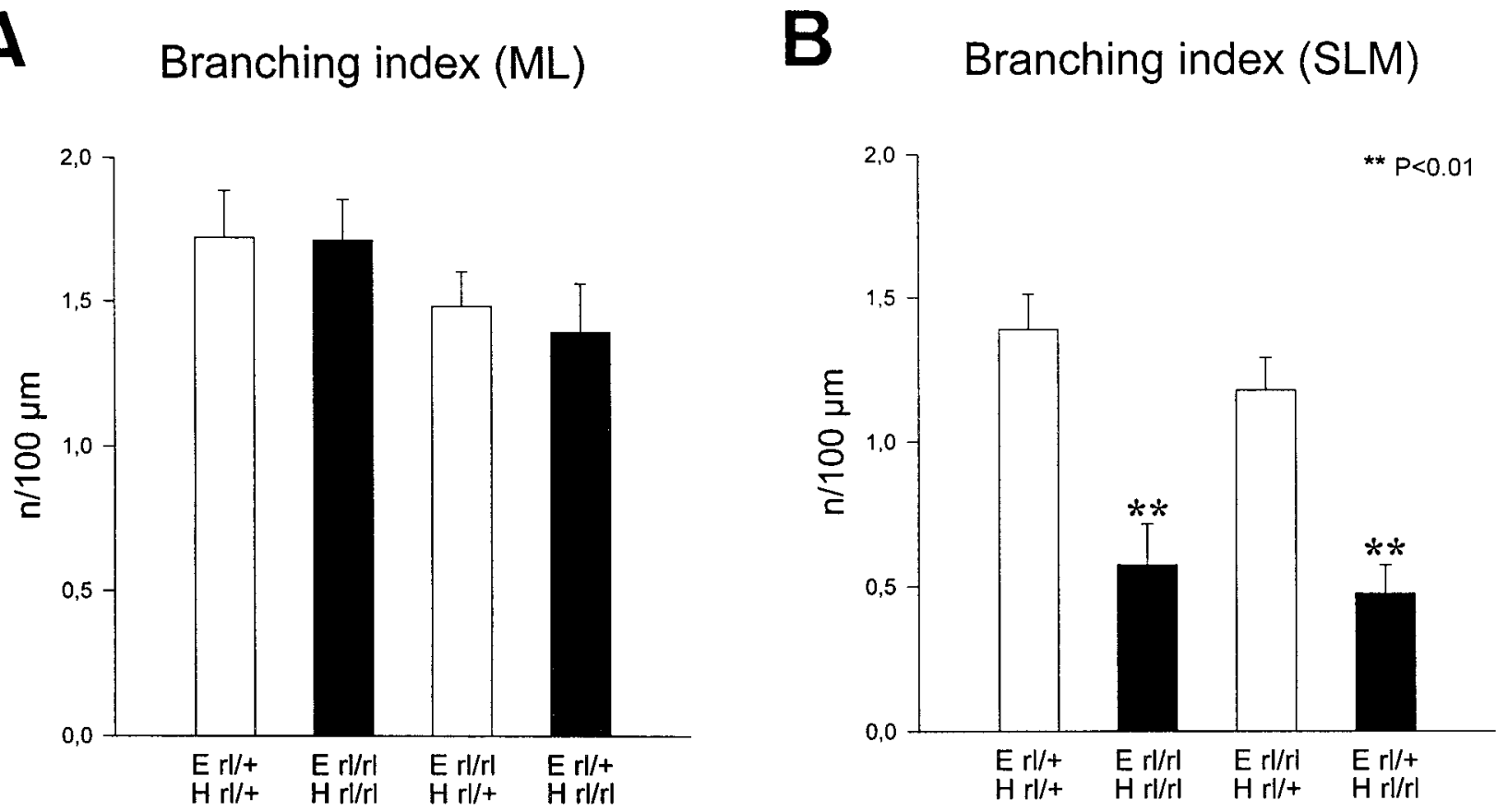

Figure 9. Branching index (number of axon branching points per $100 \mu \mathrm{m}$; mean \pm SEM) of single entorhinal fibers in heterozygous, reeler, and mixed organotypic co-cultures in the molecular layer $(M L)$ of the dentate gyrus, and the stratum lacunosum-moleculare $(S L M)$ of the hippocampus proper. Although there are no significant differences in the molecular layer, in the stratum lacunosum-moleculare, fibers have fewer axon collaterals in $r l / r l$ co-cultures and in mixed co-cultures composed of $r l / r l$ hippocampus slices. Statistically significant differences are indicated $\left({ }^{* *} p<0.01 ;\right.$ ANOVA, LSD test).

neuronal migration resembling those of reeler mice (Ohshima et al., 1996; Chae et al., 1997; Goldowitz et al., 1997; González et al., 1997; Howell et al., 1997a; Sheldon et al., 1997). The recent observation of mDab1 protein in fiber tracts during ontogenesis (Howell et al., 1997b; Rice et al., 1998) suggests that these proteins may also act in signal transduction pathways triggered by Reelin in developing axons.

\section{REFERENCES}

Alcántara S, de Lecea L, Del Río JA, Ferrer I, Soriano E (1996) Transient colocalization of parvalbumin and calbindin D28k in the postnatal cerebral cortex: evidence for a phenotypic shift in developing nonpyramidal neurons. Eur J Neurosci 8:1329-1339.

Alcántara S, Ruiz M, D’Arcangelo G, Ezan F, de Lecea L, Curran T, Sotelo C, Soriano E (1998) Regional and cellular patterns of reelin mRNA expression in the forebrain of the developing and adult mouse. J Neurosci 17:7779-7799.

Amaral DG, Witter MP (1995) Hippocampal formation. In: The rat nervous system, Ed 2 (Paxinos G, ed), pp 443-493. New York: Academic.

Blackstad TW (1956) Commissural connections of the hippocampal region in the rat, with special reference to their mode of termination. J Comp Neurol 105:417-537.

Brennan C, Monschau B, Lindberg R, Guthrie B, Drescher U, Bonhoeffer F, Holder N (1997) Two Eph receptor tyrosine kinase ligands control axon growth and may be involved in the creation of the retinotectal map in the zebrafish. Development 124:655-664.

Cabelli RJ, Hohn A, Shatz CJ (1995) Inhibition of ocular dominance column formation by infusion of NT4/5 or BDNF. Science 267:1662-1666.

Causing CG, Gloster A, Aloyz R, Bamji SX, Chan E, Fawcett J, Kuchel G, Miller FD (1997) Synaptic innervation density is regulated by neuron-derived BDNF. Neuron 18:257-267.

Chae T, Kwon YT, Bronson R, Dikkes P, Li E, Tsai LH (1997) Mice lacking p35, a neuronal specific activator of $\mathrm{Cdk} 5$, display cortical lamination defects, seizures, and adult lethality. Neuron 18:29-42.

Chédotal A, Del Río JA, Ruiz M, He Z, Borrell V, de Castro F, Ezan F, Goodman C, Tessier-Lavigne M, Sotelo C, Soriano E (1998) Semaphorins III and IV repel hippocampal axons via two distinct receptors. Development 125:4313-4323.
Cheng HJ, Nakamoto M, Bergemann AD, Flanagan JG (1995) Complementary gradients in expression and binding of ELF-1 and Mek4 in development of the topographic retinotectal projection map. Cell 82:371-381.

Cohen-Cory S, Fraser SE (1995) Effects of brain-derived neurotrophic factor on optic axon branching and remodeling in vivo. Nature 378:192-196.

Culotti JG, Kolodkin AL (1996) Functions of netrins and semaphorins in axon guidance. Curr Opin Neurobiol 6:81-88.

D'Arcangelo G, Miao GG, Chen S-C, Soares H, Morgan JI, Curran T (1995) A protein related to extracellular matrix proteins deleted in the mouse mutant reeler. Nature 374:719-723.

D'Arcangelo G, Nakajima K, Miyata T, Ogawa M, Mikoshiba K, Curran T (1997) Reelin is a secreted glycoprotein recognized by the CR-50 monoclonal antibody. J Neurosci 17:23-31.

de Lecea L, Soriano E, Criado JR, Steffensen SL, Henriksen SJ, Sutcliffe JG (1994) Transcripts encoding a neural membrane CD26 peptidaselike protein are stimulated by synaptic activity. Mol Brain Res 25:286-296.

Del Río JA, Martínez A, Fonseca M, Auladell C, Soriano E (1995) Glutamate-like immunoreactivity and fate of Cajal-Retzius cells in the murine cortex as identified with calretinin antibody. Cereb Cortex 5:13-21

Del Río JA, Heimrich B, Supèr H, Borrell V, Frotscher M, Soriano E (1996) Differential survival of Cajal-Retzius cells in organotypic cultures of hippocampus and neocortex. J Neurosci 16:6896-6907.

Del Río JA, Heimrich B, Borrell V, Förster E, Drakew A, Alcántara S, Nakajima K, Miyata T, Ogawa M, Mikoshiba K, Derer P, Frotscher M, Soriano E (1997) A role for Cajal-Retzius cells and reelin in the development of hippocampal connections. Nature 385:70-74.

Derer P, Derer M (1990) Cajal-Retzius cell ontogenesis and death in mouse brain visualized with horseradish peroxidase and electron microscopy. Neuroscience 36:839-856.

Desai CJ, Gindhart Jr JG, Goldstein LS, Zinn K (1996) Receptor tyrosine phosphatases are required for motor axon guidance in the Drosophila embryo. Cell 84:599-609.

Drescher U, Kremoser C, Handwerker C, Löschinger J, Noda M, Bonhoeffer F (1995) In vitro guidance of retinal ganglion cell axons by RAGS, a $25 \mathrm{kDa}$ tectal protein related to ligands for Eph receptor tyrosine kinases. Cell 82:359-370. 
Edmunds SM, Parnavelas JG (1982) Retzius-Cajal cells: an ultrastructural study in the developing visual cortex of the rat. J Neurocytol 11:427-446.

Faissner A (1997) The tenascin gene family in axon growth and guidance. Cell Tissue Res 290:331-341.

Förster E, Kaltschmidt C, Deng J, Cremer H, Deller T, Frotscher M (1998) Lamina-specific cell adhesion on living slices of hippocampus. Development 125:3399-3410.

Frotscher M, Heimrich B (1993) Formation of layer-specific fiber projections to the hippocampus in vitro. Proc Natl Acad Sci USA 90:10400-10403.

Fujisawa H, Kitsukawa T, Kawakami A, Takagi S, Shimizu M, Hirata T (1997) Roles of a neuronal cell-surface molecule, neuropilin, in nerve fiber fasciculation and guidance. Cell Tissue Res 290:465-470.

Goffinet AM (1997) Unscrambling a disabled brain. Nature 389:668-669.

Goldowitz D, Cushing RC, Laywell E, D'Arcangelo G, Sheldon M, Sweet HO, Davisson MT, Steindler D, Curran T (1997) Cerebellar disorganization characteristic of reeler in scrambler mutant mice despite presence of Reelin. J Neurosci 17:8767-8777.

González JL, Russo CJ, Goldowitz D, Sweet HO, Davisson MT, Walsh CA (1997) Birthdate and cell marker analysis of scrambler: a novel mutation affecting cortical development with a Reeler-like phenotype. J Neurosci 17:9204-9211.

Goodman CS (1996) Mechanisms and molecules that control growth cone guidance. Annu Rev Neurosci 19:341-377.

Gotz M, Bolz J, Joester A, Faissner A (1997) Tenascin-C synthesis and influence on axonal growth during rat cortical development. Eur J Neurosci 9:496-506.

Hirotsune S, Takahara T, Sasaki K, Hirose K, Yoshiki A, Ohashi T, Kusakabe M, Murakami Y, Muramutsu M, Watanabe S, Nakao K, Katsuki M, Hayashizaki Y (1995) The reeler gene encodes a protein with an EGF-like motif expressed by pioneer neurons. Nat Genet 10:77-83.

Holt CE, Harris WA (1998) Target selection: invasion, mapping and cell choice. Curr Opin Neurobiol 8:98-105.

Howell BW, Hawkes R, Soriano P, Cooper JA (1997a) Neuronal position in the developing brain is regulated by mouse disabled-1. Nature 389:733-737.

Howell BW, Gertler FB, Cooper JA (1997b) Mouse disabled (mDab1): a Src binding domain implicated in neuronal development. EMBO J 16:121-132.

Inoue A, Sanes JR (1997) Lamina-specific connectivity in the brain: regulation by $\mathrm{N}-\mathrm{Cadherin}$, neurotrophins, and glycoconjugates. Science 276:1428-1431.

Katz LC, Shatz CJ (1996) Synaptic activity and the construction of cortical circuits. Science 274:1133-1138.

Lin DM, Fetter RD, Kopczynski C, Grenningloh G, Goodman CS (1994) Genetic analysis of Fasciclin II in Drosophila: defasciculation, refasciculation, and altered fasciculation. Neuron 13:1055-1069.

Lorente de Nó R (1934) Studies on the structure of the cerebral cortex. II. Continuation of the study of the ammonic system. J Psychol Neurol 46:113-177.

Marín-Padilla M (1978) Dual origin of the mammalian neocortex and evolution of the cortical plate. Anat Embryol 152:109-126.

Marín-Padilla M, Marín-Padilla MT (1982) Origin, prenatal development and structural organization of layer I of the human cerebral (motor) cortex: a Golgi study. Anat Embryol 164:161-206.

Martínez A, Alcántara S, Borrell V, Del Río JA, Blasi J, Otal R, Campos N, Boronat A, Barbacid M, Silos-Santiago I, Soriano E (1998) TrkB and TrkC signaling are required for maturation and synaptogenesis of hippocampal connections. J Neurosci 18:7336-7350.

Matthes DJ, Sink H, Kolodkin AL, Goodman CS (1995) Semaphorin II can function as a selective inhibitor of specific synaptic arborizations. Cell 81:631-639.

Messersmith EK, Leonardo D, Shatz CJ, Tessier-Lavigne M, Goodman CS, Kolodkin AL (1995) Semaphorin III can function as a selective chemorepellent to pattern sensory projections in the spinal cord. Neuron 14:949-959.

Nakajima N, Mikoshiba K, Miyata T, Kudo C, Ogawa M (1997) Disruption of hippocampal development in vivo by CR-50 mAb against Reelin. Proc Natl Acad Sci USA 94:8196-8201.

Ogawa M, Miyata T, Nakajima K, Yagyu K, Seike M, Ikenaka K, Yamamoto H, Mikoshiba K (1995) The reeler gene-associated antigen on Cajal-Retzius neurons is a crucial molecule for laminar organization of cortical neurons. Neuron 14:899-912.

Ohshima T, Ward JM, Huh CG, Longenecker G, Veeranna Pant HC,
Brady RO, Martin LJ, Kulkarni AB (1996) Targeted disruption of the cyclin-dependent kinase 5 gene results in abnormal corticogenesis, neuronal pathology and perinatal death. Proc Natl Acad Sci USA 93:11173-11178.

Püschel AW, Adams RH, Betz H (1995) Murine semaphorin D/Collapsin is a member of a diverse gene family and creates domains inhibitory for axonal extension. Neuron 14:941-948.

Rice DS, Sheldon M, D'Arcangelo G, Nakajima K, Goldowitz D, Curran $\mathrm{T}$ (1998) Disabled-1 acts downstream of Reelin in a signaling pathway that controls laminar organization in the mammalian brain. Development 125:3719-3729.

Ruth RE, Collier TJ, Routtenberg A (1982) Topography between the entorhinal cortex and the dentate septotemporal axis in rats. I. Medial and intermediate entorhinal projecting cells. J Comp Neurol 209:69-78.

Schiffmann SN, Bernier B, Goffinet A (1997) Reelin mRNA expression during mouse brain development. Eur J Neurosci 9:1055-1071.

Serafini T, Colamarino SA, Leonardo ED, Wang H, Beddington R, Skarnes WC, Tessier-Lavigne M (1996) Netrin-1 is required for commissural axon guidance in the developing vertebrate nervous system. Cell 87:1001-1014.

Sheldon M, Rice DS, D'Arcangelo G, Yoneshima H, Nakajima K, Mikoshiba K, Howell BW, Cooper JA, Goldowitz D, Curran T (1997) Scrambler and yotari disrupt the disabled gene and produce a reelerlike phenotype in mice. Nature 389:730-733.

Snider WD, Litchman J (1996) Are neurotrophins synaptotrophins?. Mol Cell Neurosci 7:433-442.

Soriano E, Del Río JA, Martínez A, Supèr H (1994) Organization of the embryonic and early postnatal murine hippocampus. I. Immunocytochemical characterization of neuronal populations in the subplate and marginal zone. J Comp Neurol 342:571-595.

Stanfield BB, Caviness VS, Cowan WM (1979) The organization of certain afferents to the hippocampus and dentate gyrus in normal and reeler mice. J Comp Neurol 185:461-483.

Steward O (1976) Topographic organization of the projections from the entorhinal area to the hippocampal formation in the rat. J Comp Neurol 167:285-314.

Steward O, Scoville SA (1976) Cells of origin of entorhinal cortical afferents to the hippocampus and fascia dentata of the rat. J Comp Neurol 169:347-370.

Stoeckli ET, Landmesser LT (1995) Axonin-1, Nr-CAM, and Ng-CAM play different roles in the in vivo guidance of chick commissural neurons. Neuron 14:1165-1179.

Stoppini L, Buchs PA, Müller D (1991) A simple method for organotypic cultures of nervous tissue. J Neurosci Methods 37:173-182.

Supèr H, Soriano E (1994) The organization of the embryonic and early postnatal murine hippocampus. II. Development of entorhinal, commissural, and septal connections studied with the lipophilic tracer DiI. J Comp Neurol 344:101-120.

Supèr H, Martínez A, Del Río JA, Soriano E (1998a) Involvement of distinct pioneer neurons in the formation of layer-specific connections in the hippocampus. J Neurosci 18:4616-4626.

Supèr H, Soriano E, Uylings HB (1998b) The functions of the preplate in development and evolution of the neocortex and hippocampus. Brain Res Rev 27:40-64.

Swanson LW, Cowan WM (1977) An autoradiographic study of the organization of the efferents connections of the hippocampal formation in the rat. $\mathrm{J}$ Comp Neurol 172:49-84.

Swanson LW, Wyss JM, Cowan WM (1978) An autoradiographic study of the organization of intrahippocampal association pathways in the rat. J Comp Neurol 181:681-716.

Tang J, Landmesser L, Rutishauser U (1992) Polysialic acid influences specific pathfinding by avian motoneurons. Neuron 8:1031-1044.

Tessier-Lavigne M, Goodman CS (1996) The molecular biology of axon guidance. Science 274:1123-1133.

Wadsworth WG, Bhatt H, Hedgecock EM (1996) Neuroglia and pioneer neurons express UNC-6 to provide global and local netrin cues for guiding migrations in C. elegans. Neuron 16:35-46.

Wang HU, Anderson AJ (1997) Eph Family transmembrane ligands can mediate repulsive guidance of trunk neural crest migration and motor axon outgrowth. Neuron 18:383-396.

Winslow JW, Moran P, Valverde J, Shih A, Yuan JQ, Wong SC, Tsai SP, Goddard A, Henzel WJ, Hefti F, Beck KD, Caras IW (1995) Cloning of AL-1, a ligand for an Eph-related tyrosine kinase receptor involved in axon bundle formation. Neuron 14:973-981. 